e-Journal Al-Syakhsiyyah: Journal of Law \& Family Studies, Vol. 2 No.1 (2020)

(c) Fakultas Syariah IAIN Ponorogo (2020)

Published Online ; Juni 2020

\title{
KAJIAN PERATURAN MENTERI AGAMA RI NOMOR 52 TAHUN 2014 TERHADAP PENDAYAGUNAAN ZAKAT PRODUKTIF BAZNAS KOTA MADIUN
}

\author{
Atik Abidah \\ Fakultas Syariah IAIN Ponorogo \\ Atik.abidah080576@gmail.com \\ Yuniar Fathiyyatur Rosyida \\ Fakultas Syariah IAIN Ponorogo \\ yuniarelkhanza456@gmail.com
}

\begin{abstract}
ABSTRAK : Islam tumbuh dengan banyak kepedulian positif terhadap realitas suatu permasalahan, termasuk fenomena perekonomian, salah satunya adalah nilai filantropi dalam kewajiban zakat. Pengembangan pengelolaan zakat salah satunya adalah dengan produktifitas zakat, yang seharusnya mampu berperan dalam mengatasi pelbagai permasalahan ekonomi. Salah satu lembaga zakat yang menerapkan metode pendayagunaan zakat secara produktif adalah Baznas Kota Madiun yaitu dengan melalui program Bisafari. Begitu juga pemerintah melalui Peraturan Menteri Agama Nomor 52 tahun 2014 telah mengatur mengenai pendayagunaan zakat produktif tersebut. Salah satu syaratnya adalah bahwa kebutuhan dasar mustahik sudah terpenuhi, memenuhi ketentuan Syariah, dan menghasilkan nilai tambah ekonomi. Demikian juga halnya terkait pembuatan laporan tentang produktifitas zakat, dalam aturan tersebut, laporan dilakukan setiap 6 bulan sekali dan harus mencantumkan perkembangan Mustahiq. Hasil dari penelitian tentang pendayagunaan zakat di BAZNAS Kota Madiun, Pertama, tentang kriteria Mustahik dalam Program Bisafari belum sepenuhnya sesuai dengan peraturan Menag No. 52 Tahun 2014, dalam praktiknya, di Kota Madiun masih terdapat mustahiq yang tidak bisa mengembangkan usahanya dengan bantuan tersebut, artinya belum bisa berdaya secara ekonomi. Kedua, kajian Peraturan Menteri Agama Nomor 52 Tahun 2014 terhadap pelaporan zakat produktif di Baznas Kota Madiun dengan program bisafarinya adalah belum sesuai dengan Pasal 35 ayat (4) yaitu Baznas Kota Madiun hanya membuat laporan keuangan Baznas setiap setahun sekali, dan dalam pembuatan laporan tersebut tidak dicantumkan mengenai perkembangan para mustahiq, sehingga tidak diketahui apakah ada perubahan dari pemberdayaan dana zakat tersebut.
\end{abstract}

Kata Kunci: Pendayagunaan, produktifitas, zakat, mustahiq, BAZNAS

ABSTRACT : Islam grows with many positive concerns about the reality of a problem, it is including the economic phenomena, one of which is the value of philanthropy in the 
KAJIAN PERATURAN MENTERI AGAMA RI NOMOR 52 TAHUN 2014 TERHADAP PENDAYAGUNAAN ZAKAT PRODUKTIF BAZNAS KOTA MADIUN

obligation of zakat. One of the developments of zakat management is zakat productivity, which should be able to play a role in overcoming various economic problems. One of the zakat institutions that applies zakat utilization methods productively is Baznas Madiun City through the Bisafari program. Likewise, the government through Regulation of the Minister of Religion Affair Number 52 of 2014 has regulated the utilization of this productive zakat. One of the conditions is that the basic needs of the mustahik have been met, comply with Sharia provisions, and generate economic added value. Likewise, regarding the making of reports on zakat productivity, in this regulation, reports are carried out every 6 months and must include Mustahiq's progress. The results of research on the utilization of zakat in BAZNAS Madiun City. First, the Mustahik criteria in the Bisafari Program are not fully by Minister of Religion Regulation No. 52 of 2014, in practice, in Madiun City there are still mustahiqs who cannot develop their business with this assistance, meaning that they cannot be economically empowered. Second, the study of Regulation of the Minister of Religion Number 52 of 2014 on the reporting of productive zakat at Baznas Madiun City with its bisafar program is not by Article 35 paragraph (4), namely Baznas Madiun City only makes Baznas financial reports once a year, and in making the report does not it is stated about the development of the mustahiq, so it is not known whether there has been any change from the empowerment of the zakat fund.

Keyword: Empowering, Productivity, Zakat, Mustahiq, BAZNAS

\section{PENDAHULUAN}

Hingga saat ini, permasalahan perekonomian menempati pokok pembahasan yang pelik dibandingkan permasalahan lainnya. Karena itu, ekonomi merupakan salah satu faktor terpenting terhadap jatuh bangunnya suatu pemerintahan. ${ }^{1}$ Islam bukanlah agama yang membiarkan segala permasalahan ini hadir tanpa batasan. Namun, Islam tumbuh dengan banyak kepedulian positif terhadap realitas suatu permasalahan, seperti fenomena perekonomian tersebut. Zakat yang merupakan rukun iman ketiga dianggap mempunyai peran yang signifikan dalam mengatasi pelbagai permasalahan ekonomi. $^{2}$

Zakat adalah salah satu cara untuk mendistribusikan kekayaan (harta) dalam suatu perekonomian khususnya dari yang beruntung atau kaya kepada mereka yang tidak beruntung (miskin) dalam hal mencari rezeki. Zakat akan menjadikan perekonomian bergerak cepat, terbangun persaudaraan di antara

\footnotetext{
${ }^{1}$ Yusuf Qardhawi, Spektrum Zakat Dalam Membangun Ekonomi Kerakyatan (Jakarta: Zikrul Hakim, 2005), 2.

${ }^{2}$ Nurul Huda, Novarini, Dkk, Zakat Perspektif Mikro Makro Pendekatan Riset (Jakarta: Prenadamedia Group, 2015), 1.
} 
KAJIAN PERATURAN MENTERI AGAMA RI NOMOR 52 TAHUN 2014 TERHADAP PENDAYAGUNAAN ZAKAT PRODUKTIF BAZNAS KOTA MADIUN

pelaku ekonomi, dan kesenjangan ekonomi pun akan menyempit. Zakat dengan kata lain dapat digunakan sebagai pendorong dan pengendali perekonomian agar tercapai falah (kesejahteraan lahir, batin, dunia dan akhirat) baik generasi sekarang maupun yang akan datang.

Zakat berarti harta yang wajib dikeluarkan dari kekayaan orang-orang kaya untuk disampaikan kepada mereka yang berhak menerimanya, dengan aturan-aturan yang telah ditentukan di dalam syara'. ${ }^{3}$ Zakat secara etimologi dapat diartikan berkembang dan berkah. Selain itu, zakat dapat diartikan mensucikan. Zakat disebut demikian karena harta kekayaan yang dizakati akan semakin berkembang berkat dikeluarkan zakatnya dan doa orang yang menerimanya. ${ }^{4}$

Dewasa ini, pembagian zakat yang dikelola oleh lembaga zakat pada umumnya dikelola secara konsumtif. Sedangkan, tujuan zakat tidak hanya sekadar menyantuni orang miskin secara konsumtif saja, tetapi mempunyai tujuan yang lebih permanen yaitu mengentaskan kemiskinan. ${ }^{5}$ Salah satu cara untuk mengentaskan kemiskinan melalui zakat adalah dengan mengelolanya secara produktif. Dengan mendayagunakan zakat secara produktif selain dapat digunakan sebagai alternatif pengentasan kemiskinan juga bisa digunakan untuk mengurangi jumlah pengagguran di Indonesia.

Modal dari dana zakat yang didayagunakan tersebut dapat mengembangkannya untuk memenuhi kebutuhan sehari-hari mereka. Sedangkan pemberian harta zakat dengan cara konsumtif itu akan membuat orang-orang yang menerima zakat menjadi pemalas dan selalu berharap kemurahan hati si muzakki. Dengan dana zakat yang telah diproduktifkan tersebut, mustahik tersebut dapat mempunyai penghasilan tetap, meningkatkan dan mengembangkan usahanya, serta dapat menyisihkan hasil usahanya untuk menabung. Sehingga mereka juga berpotensi menjadi muzakki di kemudian hari.

Baznas Kota Madiun adalah salah satu lembaga zakat yang menerapkan metode pendayagunaan dana zakat secara produktif. Dalam Peraturan Menteri Agama Nomor 52 Tahun 2014 disebutkan bahwa zakat dapat didayagunkan

\footnotetext{
${ }^{3}$ Abdul Ghofur Anshori, Hukum Dan Pemberdayaan Zakat Upaya Sinergis Wajib Zakat Dan Pajak di Indonesia (Yogyakrta: Pilar Media (Anggota Ikapi, 2016), 12.

${ }^{4}$ Abdul Aziz Muhammad Azzam Dan Abdul Wahhab Sayyed Hawwas, Figh Ibadah Thaharah, Shalat, Zakat, Puasa, Dan Haji (Jakarta: Amzah, 2009), 343.

5 Abdurrahman Qadir, Zakat Dalam Dimensi Mahdah Dan Sosial (Jakarta: Grafindo Persada, 2001), 83-84.
} 
KAJIAN PERATURAN MENTERI AGAMA RI NOMOR 52 TAHUN 2014 TERHADAP PENDAYAGUNAAN ZAKAT PRODUKTIF BAZNAS KOTA MADIUN

untuk usaha produktif dalam rangka penanganan fakir miskin dan peningkatan kualitas umat. $^{6}$ Dalam peraturan tersebut juga mensyaratkan adanya nilai tambah ekonomi untuk mustahiq. Ini berarti Peraturan Menteri Agama tersebut juga mendukung adanya pendayagunaan zakat produktif.

Selain mengatur mengenai persyaratan adanya zakat produktif, dalam Peraturan Menteri Agama tersebut juga mengatur tentang pelaporan yang harus dilakukan oleh lembaga zakat sebagai pengelola dana zakat ummat. Dalam pasal 35 disebutkan komponen yang harus ada dalam pelaporan tersebut setidaknya memuat mengenai identitas mustahiq, identitas lembaga pengelola zakat, jenis usaha produktif, lokasi usaha produktif, jumlah dana yang disalurkan, dan pengembangan usahanya. Hal ini dimaksudkan untuk mengontrol perkembangan mustahiq agar kehidupan mereka benar-benar mengalami kenaikan dibidang ekonomi dan mengantarkan mereka untuk menjadi muzakki.

Baznas Kota Madiun adalah lembaga non struktural yang dibentuk pemerintah, bersifat mandiri dan bertanggungjawab kepada pemerintah dan masyarakat sesuai tingkatannya. Tujuan daripada Baznas Kota Madiun diantaranya upaya mewujudkan kesejahteraan dan keadilan sosial, dan meningkatkan hasil guna dan daya guna ZIS. ${ }^{7}$ Dalam mewujudkan tujuan tersebut, Baznas Kota Madiun membentuk program zakat produktif dan solutif untuk masyarakat dhuafa, diantaranya dalam program Bisafari.

Program Bisafari yang merupakan sub program daripada Madiun Makmur adalah program dalam bentuk pemberdayaaan ekonomi prduktif yang dikelola secara sistematis, intensif dan berkesinambungan. Dalam program ini, ada produk-produk yang dijalankan diantaranya Bisafari (Bina Usaha Dhuafa Mandiri), bisafari yatim piatu dan bisafari bermitra ${ }^{8}$. Menurut Bapak Muhammad Dahlan program tersebut diadakan guna membantu para dhuafa untuk lebih giat bekerja yang ditunjang dengan bantuan peralatan kerja atau bantuan lain untuk mengembangkan usahanya dari dana zakat. Pendayagunaan seperti ini diharapkan bisa memperbaiki keadaan ekonomi para dhuafa dan jangka panjangnya dapat merubah statusnya menjadi mustahik. ${ }^{9}$

\footnotetext{
${ }^{6}$ Peraturan Menteri Agama RI Nomor 52 Tahun 2014.

${ }^{7}$ Baznas Kota Madiun, Diakses Dari https://baz.madiunkota.go.id/index.php/info-kami Pada Tanggal 9 Desember 2019 Pukul 05.18 WIB

${ }^{8}$ Badan Amil Zakat Nasional Kota Madiun, Rapat Kerja (Raker) Xiii Badan Amil Zakat Nasional Kota Madiun Program Kegiatan Tahun 2019 (Madiun: Baznas Kota Madiun, 2019), 17.

${ }^{9}$ Muhammad Dahlan, Hasil Wawancara, Madiun. 21 Oktober 2019.
} 
Program pendayagunaan yang baik harus diimbangi dengan sistem pelaporan pendayagunaan yang baik pula. Baznas Kota Madiun dalam menjaga transparansi pelaporan zakatnya membuat laporan keuangan dalam bentuk majalah yang diterbitkan setiap tiga bulan sekali. Majalah tersebut dinamakan dengan majalah WARTA. Majalah tersebut akan disebarluaskan kepada masyarakat, agar masyarakat juga ikut mengawasi kinerja daripada baznas. Selain itu, setiap akhir tahun, Baznas Kota Madiun membuat laporan akhir tahun yang akan dilaporkan kepada Gubernur atau Walikota Dan Baznas Provinsi.

Dalam praktiknya di lapangan, masih ditemukan bantuan baznas yang tidak dimanfaatkan dengan baik oleh si penerima zakat. Peneliti menemukan masih terdapat bantuan yang tidak dimanfaatkan lagi oleh pemiliknya, bahkan ada yang dijual kepada orang lain. Padahal bantuan tersebut seharusnya bisa dipergunakan dengan sebaik mungkin oleh pemiliknya untuk membantu menunjang perekonomiannya.

\section{PENDAYAGUNAAN DAN PELAPORAN ZAKAT PRODUKTIF DALAM PERATURAN MENTERI AGAMA NOMOR 52 TAHUN 2014 TENTANG SYARAT DAN TATA CARA PENGHITUNGAN ZAKAT MAL DAN ZAKAT FITRAH SERTA PENDAYAGUNAAN ZAKAT UNTUK USAHA PRODUKTIF.}

Zakat produktif adalah pemberian zakat yang dapat membuat para penerimanya menghasilkan sesuatu secara terus-menerus, dengan harta zakat yang telah diterimanya. Dengan demikian zakat produktif merupakan zakat di mana harta atau dana zakat yang diberikan kepada para mustahiq tidak dihabiskan, akan tetapi dikembangkan dan digunakan untuk membantu usaha mereka, sehingga dengan usaha tersebut mereka dapat memenuhi kebutuhan hidup secara terus-menerus.

Pendayagunaan zakat adalah segala sesuatu yang berkaitan dengan usaha pemerintah dalam memanfaatkan hasil pengumpulan zakat untuk didistribusikan kepada mustahiq (sasaran penerima zakat) dengan berpedoman syariah, tepat guna, serta pemanfaatan yang efektif melalui pola pendistribusian yang bersifat produktif dan memiliki manfaat sesuai dengan tujuan ekonomis dari zakat. ${ }^{10}$

${ }^{10}$ Sjechul Hadi Permono, Pendayagunaan Zakat Dalam Rangka Pembangunan Nasional (Jakarta: Pustaka Firdaus, 1992), 41. 
KAJIAN PERATURAN MENTERI AGAMA RI NOMOR 52 TAHUN 2014 TERHADAP PENDAYAGUNAAN ZAKAT PRODUKTIF BAZNAS KOTA MADIUN

Selain itu, pendayagunaan zakat adalah usaha untuk menjadikan zakat berfungsi sebagai amal ibadah dan juga sebagai konsep sosial. Pendayagunaan ini diharapkan akan tercipta pemahaman dan kesadaran serta membentuk sikap dan perilaku hidup individu dan kelompok menuju kemandirian. ${ }^{11}$ Dengan demikian, pendayagunaan adalah upaya penguatan posisi sosial dan ekonomi dengan tujuan mencapai penguatan kemampuan umat melalui dana bantuan yang pada umumnya berupa bantuan modal untuk usaha produktif sehingga mustahiq sanggup meningkatkan pendapatannya dan juga membayar kewajibannya (zakat) dari hasil usahanya tersebut.

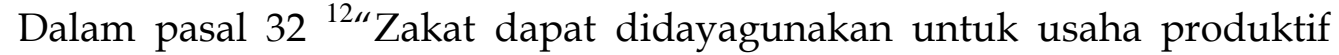
dalam rangka penanganan fakir miskin dan peningkatan kualitas umat."

Pendayagunaan dana zakat secara produktif adalah salah satu bentuk pengelolaan zakat dengan memanfaatkan sumber daya (dana zakat) secara maksimal sehingga dapat berdayaguna dalam jangka yang panjang dan dapat membawa kemashlahatan bagi umat, khususnya bagi para mustahiq, biasanya dalam bentuk usaha produktif, baik dengan pemberian modal pengusaha lemah, pembinaan kewirausahaan, pendidikan gratis, dan sebagainya, dengan upaya ini diharapkan dapat meningkatkan kesejahteraan dan taraf hidup mustahiq menjadi lebih baik dan bisa mandiri secara ekonomi.

Selanjutnya dalam Pasal $33^{13}$ menyebutkan syarat terkait dengan pendayagunaan zakat produktif adalah sebagai berikut:

1. Apabila kebutuhan dasar mustahiq telah terpenuhi. Menurut penjelasan atas Undang-Undang RI Nomor 23 Tahun 2011 Tentang Pengelolaan Zakat yang dimaksud dengan kebutuhan dasar mustahiq meliputi kebutuhan sandang, pangan, perumahan, pendidikan, dan kesehatan. ${ }^{14}$

2. Memenuhi ketentuan syariah. Menurut Mu'inan Rafi dalam hal ini ketentuan syariah yang dimaksud setidaknya memenuhi tujuan disyariatkannya zakat yaitu untuk menghilangkan kemiskinan serta mensejahterakan kaum dhuafa, dengan harapan secara bertahap mereka tidak selamanya menjadi mustahiq melainkan menjadi muzakki. Selain itu juga memenuhi ketentuan syariah

\footnotetext{
${ }^{11}$ Ibid.,198.

12 Peraturan Menteri Agama Nomor 52 Tahun 2014

13 Ibid

${ }^{14}$ Undang-Undang RI No 23 Tahun 2011
} 
KAJIAN PERATURAN MENTERI AGAMA RI NOMOR 52 TAHUN 2014 TERHADAP PENDAYAGUNAAN ZAKAT PRODUKTIF BAZNAS KOTA MADIUN

yang lain seperti ketentuan tentang mustahiq penerima zakat dan ketentan harta yang dizakati.15

3. Menghasilkan nilai tambah ekonomi untuk mustahiq. Menurut pakar ekonomi dunia, Haller dan Stolowy nilai tambah ekonomi dapat diartikan sebagai proses perubahan kondisi perekonomian secara berkesinambungan menuju keadaan yang lebih baik selama periode tertentu.16 Nilai tambah dalam hal ini adalah objek zakat dapat dimanfaatkan dan dikembangkan lagi oleh mustahiq.

4. Mustahiq berdomisili di wilayah kerja lembaga pengelola zakat.

Dan dalam Pasal $34^{17}$ mengatur tentang ketentuan pendayagunaan zakat untuk usaha produktif sebagai berikut:

1. Penerima manfaat merupakan perorangan atau kelompok yang memenuhi kriteria mustahiq. Kriteria mustahiq diatur langsung dalam Al-Qur'an surat At-Taubah ayat 60. Kriteria mustahiq yang dimaksud adalah termasuk kedalam delapan golongan yang berhak menerima zakat yaitu fakir, miskin, amil, gharim, muallaf, riqab, fisabilillah, dan ibnu sabil. Sedangkan secara umum mustahiq zakat dapat dikelompokkan menjadi dua bagian yakni mustahiq zakat produktif dan mustahiq zakat konsumtif. Mustahiq zakat dalam kategori produktif adalah mustahiq zakat dari delapan asnaf yang mempunyai kemampuan mempunyai potensi, dan tenaga untuk bekerja. Sedangkan mustahiq zakat konsumtif adalah mustahiq dari delapan asnaf di atas terutama fakir miskin yang tidak mempunyai tenaga, cacat, dan tidak mempunyai tenaga untuk bekerja. ${ }^{18}$

2. Mendapat pendampingan dari amil zakat yang berada di wilayah domisili mustahiq. Pendampingan di sini misalnya pendampingan usaha untuk mengembangkan usaha mikro dalam bentuk alih pengetahuan, keterampilan dan informasi. ${ }^{19}$ Jadi mustahiq mendapatkan keterampilan tambahan untuk mengembangan usaha mereka.

${ }^{15}$ Elfadhli, "Zakat Produktif Sebagai Salah Satu Solusi Pengentasan Kemiskinan Dan Pengangguran Di Indonesia", Juris Vol. 14 (Juni 2015), 106.

${ }^{16}$ Henry Faizal Noor, Ekonomi Manajerial (Jakarta: Pt. Raja Grafindo Rasada, 2007), 2.

17 Peraturan Menteri Agama Nomor 52 Tahun 2014

${ }^{18}$ Muhanmmad Hasan, Manajemen Zakat Model Pengeloaan Yang Efektif (Yogyakarta: Idea Press Yogyakarta, 2011), 86-87.

19 Mu'inan Rafi', Potensi Zakat (Dari Konsumtif-Karitatif Ke Produktif-Berdayaguna) (Yogyakarta: Citra Pustaka, 2011), 82. 
KAJIAN PERATURAN MENTERI AGAMA RI NOMOR 52 TAHUN 2014 TERHADAP PENDAYAGUNAAN ZAKAT PRODUKTIF BAZNAS KOTA MADIUN

Ketentuan terkait laporan sebagaimana diatur dalam Peraturan Menteri Agama Nomor 52 Tahun 2014 pasal 35 bahwa sebuah lembaga pengelola zakat wajib melaporkan pendayagunaan zakat untuk usaha produktif. Secara berjenjang dan dilakukan setiap 6 bulan sekali atau 2 kali dalam satu tahun.

Adapun dalam laporan dimaksud paling sedikit memuat: pertama, Identitas mustahiq dalam hal ini bisa berupa KTP atau KK yang dimiliki oleh mustahiq, yang kedua Identitas lembaga pengelola zakat sesuai daerah masingmasing, yang ketiga, Jenis usaha produktif yang dapat dikembangkan oleh mustahiq, yang keempat, lokasi usaha produktif yang dilakukan mustahiq, yang kelima, jumlah dana yang disalurkan dan diberikan lembaga pengelola untuk kemudian dikelola oleh mustahiq, yang keenam, perkembangan usahanya. Yaitu laporan perubahan pasca disalurkannya dana zakat kepada mustahiq. ${ }^{20}$

Dalam hal ini, unsur-unsur tersebut harus ada dalam laporan pendayagunaan zakat untuk mengontrol perkembangan mustahiq sebelum dan sesudah diberikan bantuan.

\section{PENDAYAGUNAAN DAN PELAPORAN ZAKAT PRODUKTIF BAZNAS KOTA MADIUN.}

Sebelum tahun 1994 Kota Madiun khususnya dan karisidenan Madiun pada umumnya belum memiliki badan atau lembaga negara yang fokus dalam tugas atau fungsinya untuk mengelola dana zakat, infaq dan shodaqoh dari masyarakat. Saat itu pengelolaan zakat, infaq, shodaqoh di Kota Madiun hanya dilakukan secara insidental di bulan Ramadhan saja. Melihat potensi zakat, infaq, shodaqoh yang besar, maka dengan didahului studi banding ke BAZIS DKI Jakarta pada tahun 1994, dibentuklah BAZIS Daerah Tingkat II Kota Madya Madiun dengan keputusan walikota madya Kepala Daerah Tingkat II Madiun Nomor: 58 Tanggal 28 oktober 1994.

Sedangkan badan amil zakat (BAZ) Kota Madiun yang saat ini ada merupakan lanjutan dari BAZIS Kota Madiun yang telah terbentuk sejak tahun 1994. Kemudian, dengan keluarnya Undang-Undang Nomor 38 Tahun 1999 tentang pengelolaan zakat maka BAZIS Kota Madiun berubah namanya menjadi BAZ Kota Madiun. adapun penggantian kepengurusan BAZ Kota Madiun sejak tahun 2001 berturut-turut berlandaskan SK WaliKota Madiun. Selanjutnya, berdasarkan UU No. 23 Tahun 2011 pada awal tahun 2016 BAZ Kota Madiunberganti menjadi Baznas Kota Madiun. landasan operasional lembaga

\footnotetext{
${ }^{20}$ Peraturan Menteri Agama RI Nomor 52 Tahun 2014.
} 
KAJIAN PERATURAN MENTERI AGAMA RI NOMOR 52 TAHUN 2014 TERHADAP PENDAYAGUNAAN ZAKAT PRODUKTIF BAZNAS KOTA MADIUN

tersebut secara nasional berdasarkan UU No. 23 Tahun 2011 dan PP No. 14 Tahun 2014 serta Keputusan Menteri Agama 52 Tahun $2014^{21}$

\section{VISI DAN MISI BAZNAS KOTA MADIUN}

Visi “Menuju masyarakat Kota Madiun sadar zakat, infaq dan shodaqoh dalam rangka meningkatkankesejahteraan umat".

\section{Misi}

1. Menyelenggarakan pengelolaan zakat yang professional dan amanah

2. Meningkatkan fungsi dan peran kelembagaan pengelola zakat yang transparan dan mandiri.

3. Meningkatkan pendayagunaan zakat, infaq dan shodaqoh secara optimal.

4. Menyempurnakan kwalitas pelayanan kepada masyarakat melalui keunggulan insan.

5. Membangun kemandirian masyarakat melalui pemberdayaan secara produktif. 22

Baznas Kota Madiun dalam pengelolaan zakatnya memiliki beberapa program, yang sejalan dan selaras dengan visi misi yang ada, baik secara konsumtif maupun secara produktif sesuai dengan kebutuhan mustahiq di lingkungan Kota Madiun.

Pendayagunaan zakat produktif diantaranya program bisafari dhuafa, bisafari bermitra dan bisafari difabel. Ketiganya secara garis besar adalah sama, perbedaannya hanya terletak pada sasaran mustahiqnya saja.

1. Bisafari (bina usaha dhuafa mandiri)

Program bisafari adalah program pendayagunaan zakat yang diberikan kepada dhuafa yang memiliki sebuah usaha menengah kebawah. Pihak Baznas Kota Madiun akan memberikan bantuan tambahan modal dan bantuan alat usaha sesuai dengan jenis usaha mustahiq masing-masing. Bantuan tersebut nantinya akan dipergunakan mustahiq dalam mengembangkan usahanya, misalnya saja untuk membeli dagangan baru dll. Selain itu, keunggulan lain program ini adalah mustahiq dapat memesan alat apa yang dibutuhkan untuk mengembangkan usahanya tersebut kepada pihak baznas, kemudian pihak baznas yang akan membelikan alat usaha tersebut sesuai yang dipesan oleh mustahiq. Jumlah penerima program bisafari ini disamaratakan. Setiap

21 Baznas Kota Madiun, Https://Baz.Madiunkota.Go.Id/Indexx.Php/Info-Kami/ Diakses 2 Januari 2020 : 14:00 WIB.

22 Ibid. 
KAJIAN PERATURAN MENTERI AGAMA RI NOMOR 52 TAHUN 2014 TERHADAP PENDAYAGUNAAN ZAKAT PRODUKTIF BAZNAS KOTA MADIUN

kelurahan diberi kuota 5 penerima. Total bantuan modal usaha senilai Rp.500.000 dan bantuan alat usaha senilai Rp.1.500.000, jadi total bantuan yang diberikan baznas kepada setiap mustahiq adalah Rp.2.000.00023

2. Bisafari bermitra

Bisafari bermitra adalah program pendayagunaan zakat yang menggandeng pihak BUMN/ BUMD/ Instansi Vertikal dengan mengajukan proposal dari alokasi dana CSR (Corporate Social Responsbility). Dana yang terkumpul nantinya akan digunakan sebagai tambahan dana untuk mustahiq penerima program madiun makmur yang lain. ${ }^{24}$

3. Bisafari difabel/ yatim piatu

Program bisafari difabel/ yatim piatu adalah program pendayagunaan zakat produktif yang dikhususkan untuk para difabel atau yatim piatu yang memiliki sebuah usaha. Bisafari difabel sebenarnya sama dengan bisafari dhuafa biasa perbedaannya hanya terletak sasaran mustahiqnya saja. Jumlah penerimanya juga disesuaikan dengan program bisafari dhuafa. ${ }^{25}$

Mekanisme pendayagunaan zakat produktif di Baznas Kota Madiun sebagai berikut:

a. Ketua Baz Kelurahan mengusulkan nama-nama yang memenuhi kriteria menjadi mustahiq zakat produktif kepada Baznas Kota Madiun.

b. Pihak Baznas melakukan survey langsung kelokasi calon mustahiq.

c. Pihak Baznas Kota Madiun membuat proposal pengajuan dana CSR kepada perusahaan-perusahaan area Kota Madiun.

d. Pihak Baznas memesankan apa yang menjadi kebutuhan mustahiq sesuai dengan hasil survey awal.

e. Setelah barang pesanan sudah jadi, mustahiq akan dipanggil ke Baznas Kota Madiun untuk sosialisasi penggunaan bantuan dan untuk penandatanganan kesepakatan antara Baznas dan mustahiq.

f. Bantuan alat kerja akan diantarkan langsung ke rumah mustahiq tanpa harus mustahiq mendatangi Baznas. ${ }^{26}$

Yang menjadi sasaran atau penerima dana madiun makmur tidak semua golongan 8 asnaf tetapi mereka yang memiliki kriteria-kriteria sebagai berikut:

${ }^{23}$ Badan Amil Zakat Nasional Kota Madiun, Rapat Kerja (Raker) Xiii Badan Amil Zakat Nasional Kota Madiun Program Kegiatan Tahun 2019 (Madiun: Baznas Kota Madiun, 2019), 17.

${ }^{24}$ Ibid.,

${ }^{25}$ Ibid.,

${ }^{26}$ Alisofa.Hasil Wawancara. Madiun 8 Januari 2020. 
KAJIAN PERATURAN MENTERI AGAMA RI NOMOR 52 TAHUN 2014 TERHADAP PENDAYAGUNAAN ZAKAT PRODUKTIF BAZNAS KOTA MADIUN

a. Diusulkan oleh Petugas Relawan ZIS Kelurahan dan/atau atas rekomendasi Ketua BAZ Kelurahan

b. Penelitian kebenaran mustahiq melalui survey petugas.

c. Ikut aktif dalam kegiatan keagamaan di daerahnya ${ }^{27}$

Dari data di lapangan terkait dengan pengelolaan zakat produktif yang dilakukan BAZNAS, menunjukkan bahwa ada sebagian dari mereka yang tidak bisa mengembangkan usahanya. Mereka mengalami kesulitan dalam mempertahankan usaha mereka. Misalnya saja ibu Suparmi. Ibu Suparmi adalah penjual pecel di daerah kelurahan Pilangbango, mendapatkan bantuan etalase untuk berjualan pecelnya di rumah, namun kesulitan mempertahankan dagangan pecel didaerah tempat tinggal beliau sebab banyak yang berjualan pecel seperti usaha Ibu Suparmi. ${ }^{28}$ Selain itu, ada juga yang usahanya terus berkembang, bahkan dinilai sangat terbantu dengan adanya bantuan dari Baznas ini. Seperti Ibu Rusmini, penjual gorengan di daerah Sogaten. Ibu Rusmini bisa memanfaatkan hasil dari penjualan gorengan tersebut untuk membantu memenuhi kebutuhan sehari-hari dan untuk tambahan uang saku sekolah anaknya. ${ }^{29}$ Selain Ibu Rusmini, penulis juga mewawancarai bapak Agus Hartono. Beliau adalah penerima program bisafari tahun 2018. Usaha beliau adalah laundry. Beliau mendapatkan bantuan mesin cuci yang beliau pilih sendiri ketika diajak oleh pihak pengurus Baznas ke tempat elektronik. Hasil dari bantuan baznas tersebut dapat dipergunakan untuk biaya kuliah anaknya. ${ }^{30}$

Dalam survey lanjutan di lapangan, penulis menemukan bahwa perkembangan sebagian mustahiq penerima program pendayagunaan zakat sudah baik dan sudah berjalan. Hal ini dibuktikan dengan terlaksanakannya salah satu indikator keberhasilan pendayagunaan zakat produktif di Baznas Kota Madiun yaitu adanya peningkatan keberhasilan ekonomi rumah tangga mustahiq. Namun, dalam hal ini pihak Baznas tidak melakukan monev lagi setelah bantuan dana zakat diberikan. Meskipun tidak ada pengawasan langsung dari Baznas, mereka menyadari bahwa bantuan tidak akan ada hasilnya jika tidak dimanfaatkan sebaik mungkin dan semaksimal mungkin. Tentu saja bagi mereka yang menginginkan keadaan ekonomi yang lebih baik

${ }^{27}$ Badan Amil Zakat Nasional Kota Madiun, Rapat Kerja (Raker) Xiii Badan Amil Zakat Nasional Kota Madiun Program Kegiatan Tahun 2019 (Madiun: Baznas Kota Madiun, 2019), 17.

${ }^{28}$ Suparmi, Hasil Wawancara, Madiun 11 Januari 2020.

${ }^{29}$ Rusmini, Hasil Wawancara, Madiun 18 Januari 2020.

${ }^{30}$ Agus Hartono, Hasil Wawancara. Madiun 18 Januari 2020 
dan untuk kedepannya bisa merubah status mustahiq menjadi muzakki. Namun ada juga sebagian mustahiq yang tidak memanfaatkan dana bantuan atau bantuan alat dari baznas, bahkan ada yang menjualnya kepada orang lain.

Selain itu, seperti keterangan-keterangan yang tertera di atas, bentuk program Bisafari ini bukanlah pelatihan kemampuan untuk mustahiq namun berbentuk penambahan modal usaha dan bantuan alat usaha. Jadi mustahiq yang menerima program ini telah disurvey oleh petugas Baznas harus sudah memiliki usaha meskipun kecil-kecilan untuk kemudian diberi bantuan program ini.

Pembuatan laporan keuangan di Baznas Kota Madiun melewati beberapa proses, diantaranya:

1. Setiap dinas di Kota Madiun menyetorkan data pembayar zakat (muzakki) kepada Baznas sebulan sekali di awal bulan.

2. Baznas akan meminta data pembayar zakat kepada bank. Data tersebut adalah data umum. Artinya data tersebut belum terkelompokkan setiap dinasnya.

3. Setelah datanya sama baru ditotal jumlah zakat yang masuk ke Baznas.

Dari wawancara dengan Ibu Sholatin penulis menemukan bahwa pembuatan laporan keuangan pada Baznas Kota Madiun melewati proses yang panjang dan tidak mudah. Bentuk pelaporan tersebut berupa buku besar yang di dalamnya tercantum identitas muzakki, jumlah zakat yang dikeluarkan, pentasyarufan dana zakat, dan identitas mustahiq. Semua unsur tersebut ada dalam laporan keuangan Baznas yang diserahkan kepada Wali Kota atau Baznas Provinsi setiap setahun sekali. ${ }^{31}$

TINJAUAN PERATURAN MENTERI AGAMA RI NOMOR 52 TAHUN 2014 TERHADAP BENTUK PENDAYAGUNAAN ZAKAT PRODUKTIF PADA BAZNAS KOTA MADIUN

Peraturan Menteri Agama RI Nomor 52 Tahun 2014 membahas mengenai pendayagunaan zakat produktif, yaitu dalam Pasal 32 yang mengatur bahwa pendayagunaan zakat produktif dilaksanakan dalam rangka penanganan fakir miskin dan peningkatan kualitas umat. Sedangkan dalam Pasal 33 menyebutkan bahwa syarat dilakukannya pendayagunaan zakat produktif ini adalah apabila kebutuhan dasar mustahiq telah terpenuhi; memenuhi ketentuan syariah, menghasilkan nilai tambah ekonomi untuk mustahiq, dan mustahiq berdomisili di

${ }^{31}$ Sholatin, Hasil Wawancara, Madiun 7 Januari 2020. 
wilayah kerja lembaga pengelola zakat. Dan dalam Pasal 34 disebutkan bahwa ketentuan adanya pendayagunaan zakat prduktif ini adalah penerima manfaat merupakan perorangan atau kelompok yang memenuhi kriteria mustahiq, dan mendapat pendampingan dari amil zakat yang berada di wilayah domisili mustahiq. Pasal-pasal tersebut diatur guna pendayagunaan zakat produktif tersalurkan dengan maksimal dan tepat sasaran.

Berbicara tentang zakat tentunya selalu berbicara tentang nilai filantropi di dalamnya, zakat dengan konsep filantropinya sesungguhnya adalah bagian dari ibadah maaliyyah ijtimaiyyah, yaitu ibadah di bidang harta yang memiliki posisi sosial yang sangat penting dan menentukan. Filantropi dalam Islam seyogyanya dijadikan sebagai kebutuhan dan life style (gaya hidup) seorang Muslim. Kekuatan dan kelemahan keimanan dan keislaman seseorang antara lain ditentukan oleh sikap kedermawanan dan kepedulian sosialnya. Oleh karena itu diperlukan langkah-langkah yang strategis dan kontinyu untuk menguatkan sikap ini, antara lain melalui upaya: ${ }^{32}$

Pertama, terus menerus dilakukan edukasi dan sosialisasi kepada masyarakat tentang urgensi sikap filantropi dalam meraih kebahagiaan hidup dunia akhirat. Sarana filantropi dalam Islam, seperti kesadaran berzakat, berinfaq, bershadaqah, dan berwakaf memerlukan penguatan dan penaatan dalam pengelolaannya agar mencapai hasil yang diharapkan, yaitu berdampak terhadap kehidupan masyarakat luas.

Kedua, menguatkan peran dan manfaat badan atau lembaga yang bergerak di bidang filantropi, seperti Baznas, LAZ, dan yang lainnya agar semakin dipercaya oleh masyarakat dan mudah dijangkau oleh kalangan dhuafa. Ketika lembaga-lembaga tersebut (Baznas dan LAZ) dikelola dengan standar profesionalitas yang tinggi bukan berarti berubah menjadi "lembaga elite" yang serba birokratis dan memiliki jarak dengan kaum mustad'afin. Kualitas SDM, sistem IT yang canggih adalah justru untuk memudahkan pelayanan, baik bagi masyarakat pemberi maupun masyarakat penerima dana Ziswaf.

Ketiga, memperluas pemanfaatan dana filantropi di samping untuk halhal yang bersifat konsumtif dan sesaat, juga hal-hal yang bersifat jangka panjang dalam rangka memotong mata rantai kemiskinan, seperti biaya untuk

32 Didim Hafidhuddin, http:// www.republika.co.id/berita/kolom/wacana/18/03/17/p5qn6r396-filantropi-dalamperspektif-islam. 
KAJIAN PERATURAN MENTERI AGAMA RI NOMOR 52 TAHUN 2014 TERHADAP PENDAYAGUNAAN ZAKAT PRODUKTIF BAZNAS KOTA MADIUN

pendidikan, kesehatan, perbaikan ekonomi, penyediaan tempat tinggal yang layak, dan lain-lain.

Keempat, kerjasama dengan berbagai pihak agar gerakan filantropi ini menjadi gerakan bersama yang bersifat masif. Dalam Alquran ditegaskan. "Dan orang-orang yang beriman, lelaki dan perempuan, sebahagian mereka (adalah) menjadi penolong bagi sebahagian yang lain. Mereka menyuruh (mengerjakan) yang makruf, mencegah dari yang mungkar, mendirikan shalat, menunaikan zakat, dan mereka taat kepada Allah dan Rasul-Nya. Mereka itu akan diberi rahmat oleh Allah; sesungguhnya Allah Maha Perkasa lagi Maha Bijaksana." (QS. At-Taubah [9]: 71).

Baznas Kota Madiun melalui program Bisafari adalah progam perberdayaan ekonomi ummat, dengan mengelola zakat secara produktif yaitu zakat yang diberikan kepada mustahiq tidak langsung dihabiskan, tetapi dikembangkan dan digunakan untuk membantu usaha mereka, sehingga dengan usaha tersebut mereka dapat memenuhi kebutuhan mereka sehari-hari. Kreteria mustahiq yang berhak menerima program Bisafari ini adalah beragama Islam, warga Kota Madiun, terdapat usaha-usaha nyata yang berpeluang menguntungkan, diusulkan oleh Petugas Relawan ZIS Kelurahan dan/atau atas rekomendasi Ketua BAZ Kelurahan, penelitian kebenaran mustahiq melalui survey petugas serta ikut aktif dalam kegiatan keagamaan di daerahnya.

1. Apabila kebutuhan dasar mustahiq telah terpenuhi. Menurut penjelasan atas Undang-Undang RI Nomor 23 Tahun 2011 Tentang Pengelolaan Zakat yang dimaksud dengan kebutuhan dasar mustahiq meliputi kebutuhan sandang, pangan, perumahan, pendidikan, dan kesehatan. Sedangkan hasil penelitian yang diperoleh peneliti dilapangan menunjukkan bahwa Baznas Kota Madiun dalam menyeleksi calon mustahiq juga memperhatikan terpenuhinya kebutuhan dasar mustahiq sebelum menyalurkan dana tersebut kepada calon mustahiq. Hal ini bertujuan agar ketika dana zakat produktif disalurkan kepada para mustahiq akan dimanfaatkan untuk fokus pada pengembangan usaha mereka. Bukan lagi untuk memenuhi kebutuhan yang lain. Namun, yang perlu diperhatikan bukan berarti yang dapat memperoleh program Bisafari adalah orang yang mampu, tapi lebih kepada mustahiq yang siap untuk mengembangkan usaha mereka lebih besar dan mampu mengubah status sosial mereka menjadi muzakki dikemudian hari.

2. Memenuhi kriteria syariah. Menurut Mu'inan Rafi dalam hal ini ketentuan syariah yang dimaksud adalah ketentuan tentang mustahiq penerima zakat 
KAJIAN PERATURAN MENTERI AGAMA RI NOMOR 52 TAHUN 2014 TERHADAP PENDAYAGUNAAN ZAKAT PRODUKTIF BAZNAS KOTA MADIUN

dan ketentan harta yang dizakati. Baznas Kota Madiun dalam menyalurkan zakat produktif khusunya dalam program bisafari ini sudah memperhatikan persyaratan tersebut. Hal ini sesuai dengan keterangan yang diberikan oleh pihak Baznas dimana mustahiq harus beragama Islam dan masuk kedalam golongan orang yang berhak menerima zakat sesuai dengan ketentuan AlQur'an dalam surah At-Taubah ayat 60.

3. Menghasilkan nilai tambah ekonomi untuk mustahiq. Menurut pakar ekonomi dunia, Haller dan Stolowy nilai tambah ekonomi dapat diartikan sebagai proses perubahan kondisi perekonomian secara berkesinambungan menuju keadaan yang lebih baik selama periode tertentu. Hasil penelitian yang diperoleh oleh peneliti dilapangan menunjukkan bahwa bantuan yang diberikan oleh pihak baznas berupa bantuan modal usaha dan bantuan alat usaha sesuai dengan kebutuhan masing-masing mustahiq. Hal ini berarti bantuan yang diberikan oleh baznas Kota Madiun dalam program bisafari ini sudah sesuai dengan ketentuan tersebut.

4. Mustahiq berdoimisili di wilayah kerja lembaga pengelola zakat. Menurut keterangan dari pihak Baznas, bahwa salah satu persyaratan untuk mendapatkan program isafari ini adalah harus asli warga Kota Madiun saja. Hal ini berarti persyaratan itu sudah sesuai dengan ketentuan tersebut.

Jadi, pendayagunaan zakat produktif di Baznas Kota Madiun melalui program Bisafari ini sudah menerapkan semua persyaratan yang ada dalam Peraturan Menteri Agaman RI Nomor 52 Tahun 2014, dengan mengedepankan kebutuhan dasar mustahiq, dan lebih memprioritaskan mustahiq di wilayah kerja Kota Madiun. Namun secara keseluruhan karena tidak ada monev atau pendampingan, masih ada beberapa mustahiq yang kurang bisa untuk memanfaatkan bantuan yang diberikan baznas dengan baik, sehingga belum mampu membawa perubahan secara ekonomi yang lebih baik.

TINJAUAN PERATURAN MENTERI AGAMA RI NOMOR 52 TAHUN 2014 TERHADAP PELAPORAN PENDAYAGUNAAN ZAKAT PRODUKTIF PADA BAZNAS KOTA MADIUN

Pelaporan pendayagunaan zakat produktif diatur dalam Peraturan Menteri Agama Nomor 52 Tahun 2014 Pasal 35 ayat (1) menyebutkan bahwa "Lembaga pengelola zakat wajib melaporkan pendayagunaan zakat untuk usaha produktif". Ditambah lagi dalam pasal 35 ayat (2) bahwa "Laporan sebagaimana dimaksud pada ayat (1) disampaikan secara berjenjang". Selain itu, dalam pasal 
KAJIAN PERATURAN MENTERI AGAMA RI NOMOR 52 TAHUN 2014 TERHADAP PENDAYAGUNAAN ZAKAT PRODUKTIF BAZNAS KOTA MADIUN

35 ayat (3) Laporan sebagaimana dimaksud pada ayat (1) disampaikan setiap 6 (enam) bulan dan akhir tahun. Dan yang terakhir dalam pasal 35 ayat (4) berisikan tentang Laporan sebagaimana dimaksud pada ayat (1) paling sedikit memuat: identitas mustahiq, identitas lembaga pengelola zakat, jenis usaha produktif, lokasi usaha produktif, jumlah dana yang disalurkan; dan perkembangan usahanya.

Dalam Baznas Kota Madiun, pelaporan keuangan dana zakat, infaq dan sedekah dilaksanakan setiap setahun sekali yaitu diakhir tahun. Menurut hasil wawancara dengan Ibu Sholatin penulis menemukan bahwa bentuk pelaporan tersebut berupa buku besar yang di dalamnya tercantum identitas mustahiq, identitas lembaga zakat, jenis usaha produktif, lokasi usaha produktif, jumlah dana yang disalurkan dan perkembangan usahanya. Semua unsur tersebut ada dalam laporan keuangan Baznas yang diserahkan kepada Wali Kota atau Baznas Provinsi setiap setahun sekali.

Jika ditinjau menggunakan Peraturan Menteri Agama Nomor 52 Tahun 2014 pasal 35 terhadap pelaporan pendayagunaan zakat Baznas Kota Madiun yaitu sebagai berikut:

Dalam ayat (1) menyatakan bahwa lembaga pengelola zakat wajib melaporkan pendayagunaan zakat untuk usaha produktif. Dan dalam ayat (2) laporan tersebut disampaikan secara berjenjang. Sedangkan dalam ayat (3) laporan tersebut disampaikan setiap 6 bulan dan kahir tahun. Menurut keterangan dari pihak Baznas Kota Madiun selaku lembaga pengelola zakat dI derah Kota Madiun sudah rutin melaporkan kegiatan pendayagunaan zakat produktif tersebut setiap setahun sekali yaitu di akhir tahun. Laporan tersebut kemudian disampaikan kepada Wali Kota dan Baznas Provinsi.

Menurut keterangan tersebut dapat ditarik kesimpulan bahwa pelaporan pendayagunaan zakat produktif di Baznas Kota Madiun belum sejalan dengan ayat (3) yang menyatakan bahwa laporan pedayagunaan zakat harus dilaporkan dalam jangka waktu 6 bulan dan di akhir tahun, dikarenakan Baznas Kota Madiun dalam pelaporannya, karena keterbatasan waktu dan tenaga, maka pelaporan hanya dilakukan satu tahun sekali.

Keterangan tambahan yang diberikan baznas kepada penulis bahwa selain membuat laporan setiap akhir tahun, pihak baznas juga membuat majalah WARTA. Majalah tersebut akan diberikan kepada masyarakat luas agar masyarakat juga ikut mengawasi kinerja Baznas Kota Madiun. Majalah tersebut memuat hasil pendapatan dana zakat dan pentasyarufan dana zakat. 
KAJIAN PERATURAN MENTERI AGAMA RI NOMOR 52 TAHUN 2014 TERHADAP PENDAYAGUNAAN ZAKAT PRODUKTIF BAZNAS KOTA MADIUN

Kemudian dalam ayat (4) laporan tersebut paling sedikit memuat identitas mustahiq, identitas lembaga pengelola zakat, jenis usaha produktif, lokasi usaha produktif, jumlah dana yang disalurkan dan perkembangan usahanya. Menurut keterangan dari baznas unsur-unsur tersebut sudah ada dalam pelaporan zakat produktif di sana. Namun, mengenai perkembangan usaha musthiq memang pihak baznas belum sempat untuk melakukan controlling terhadap mustahiq yang telah menerima bantuan. Pihak baznas mengaku kekurangan personil untuk melakukan controlling secara total dan sepenuhnya terhadap para mustahiq. Untuk menyiasati hal tersebut, pihak Baznas mengandalkan kaleng S-3 yang dititipkan kepada mustahiq. Jika kaleng S-3 kembali dengan hasil yang terus meningkat dapat diartikan bahwa perekonomian mustahiq juga ikut meningkat. Begitu sebaliknya, jika kaleng S-3 tersebut tidak pasti atau bahkan tidak kembali maka itu berarti perekonomian dari mustahiq tersebut belum bisa berkembang.

Dari keterangan tersebut dapat disimpulkan bahwa, pelaporan pendayagunaan zakat produktif di Baznas belum sesuai dengan pasal 35 ayat (3) dan aat (4), yaitu mengenai waktu penyampaian pelaporan dan mengenai perkembangan mustahiq zakat produktif.

\section{PENUTUP}

Dari uraian di atas dapat disimpulkan beberapa hal pertama, tinjauan Peraturan Menteri Agama Nomor 52 Tahun terhadap bentuk pendayagunaan zakat produktif di Baznas Kota Madiun adalah sudah sesuai dengan persyaratan yang ada dalam pasal 33. Bahwa Baznas Kota Madiun dalam menyalurkan pendayagunaan zakat produktif program bisafari ini telah memperhatikan kebutuhan dasar mustahiq yang telah terpenuhi, memenuhi ketentuan syariah, menghasilkan nilai tambah ekonomi, dan berdomisili di wilayah kerja Baznas Kota Madiun. Kedua, Tinjauan Peraturan Menteri Agama Nomor 52 Tahun 2014 terhadap pelaporan zakat produksi di BaznasKota Madiun adalah belum sesuai dengan Pasal 35 ayat (3) dan ayat (4). Bahwa dalam BaznasKota Madiun hanya membuat laporan keuangan Baznas setiap setahun sekali yaitu diakhir tahun, sedangkan di dalam Peraturan Menteri Agama tersebut disebutkan bahwa laporan pendayagunaan zakat produktif dilaksanakan setiap enam bulan sekali dan setiap akhir tahun serta dalam pembuatan laporan tersebut tidak dicantumkan mengenai perkembangan para mustahiq. 


\section{DAFTAR PUSTAKA}

Anshori, Abdul Ghofur. Hukum Dan Pemberdayaan Zakat Upaya Sinergis Wajib Zakat Dan Pajak Di Indonesia. Yogyakrta: Pilar Media (Anggota Ikapi). 2016.

Azzam, Abdul Aziz Muhammad Dan Abdul Wahhab Sayyed Hawwas. Figh Ibadah Thaharah, Shalat, Zakat, Puasa, Dan Haji. Jakarta: Amzah. 2009.

Badan Amil Zakat Nasional Kota Madiun. Rapat Kerja (Raker) Xiii Badan Amil Zakat Nasional Kota Madiun Program Kegiatan Tahun 2019. Madiun: Baznas Kota Madiun. 2019.

Baznas Kota Madiun, Diakses Dari https://baz.madiunkota.go.id/index.php/info-kami (9 Desember 2019).

Elfadhli, "Zakat Produktif Sebagai Salah Satu Solusi Pengentasan Kemiskinan Dan Pengangguran Di Indonesia", Juris Vol. 14 (Juni 2015).

Hasan, Muhanmmad. Manajemen Zakat Model Pengeloaan Yang Efektif. Yogyakarta: Idea Press Yogyakarta. 2011.

Huda, Nurul, Novarini, Dkk. Zakat PerspektifMikro Makro Pendekatan Riset. Jakarta: Prenadamedia Group. 2015.

Noor, Henry Faizal. Ekonomi Manajerial. Jakarta: PT. Raja Grafindo Rasada. 2007.

Peraturan Menteri Agama RI Nomor 52 Tahun 2014 tentang Syarat Dan Tata Cara Penghitungan Zakat Mal Dan Zakat Fitrah Serta Pendayagunaan Zakat Unutk Usaha Produktif.

Permono, Sjechul Hadi. Pendayagunaan Zakat Dalam Rangka Pembangunan Nasional. Jakarta: Pustaka Firdaus. 1992.

Qadir, Abdurrahman. Zakat Dalam Dimensi Mahdah Dan Sosial. Jakarta: Grafindo Persada. 2001..

Qardhawi, Yusuf. Spektrum Zakat Dalam Membangun Ekonomi Kerakyatan. Jakarta: Zikrul Hakim. 2005.

Rafi', Mu'inan. Potensi Zakat; Dari Konsumtif-Karitatif Ke ProduktifBerdayaguna. Yogyakarta: Citra Pustaka, 2011.

Undang-Undang RI No 23 Tahun 2011 tentang Pengelolaan Zakat. 